\title{
AS MULHERES E A PRISÃO: Uma Análise do Encarceramento Feminino Ante as Violações de Direitos da Personalidade
}

\author{
Dirceu Pereira Siqueira \\ Autor correspondente. Centro Universitário Cesumar (UniCesumar). Avenida Guedner, 1610, Jardim Aclimação, Maringá, PR, Brasil. \\ http://lattes.cnpq.br/3134794995883683. https://orcid.org/0000-0001-9073-7759. dpsiqueira@uol.com.br
}

\section{Sabrina Medina Andrecioli}

Centro Universitário Cesumar (UniCesumar).

Diante de um cenário de invisibilidade, violência e descaso em que estão inseridas as mulheres em situação de cárcere, vem à tona a importância de estudar a temática do encarceramento feminino. 0 presente trabalho tem como finalidade promover reflexões sobre o sistema prisional feminino brasileiro, no qual se busca evidenciar, por meio da história, as mulheres ante o poder punitivo e seu processo de criminalização e vitimização sob uma perspectiva de gênero. Assim, é de grande importância que a análise da vulnerabilidade das mulheres em situação de cárcere se dê por intermédio de uma epistemologia e criminologia feminista comprometida com as vicissitudes de gêneros necessárias neste ambiente de punição. Verifica-se a indispensabilidade de buscar intervenções que possam melhorar as condições de vida dessa população por meio de criação de políticas públicas específicas. Para tanto, vale-se do raciocínio hipotético-dedutivo, mediante pesquisa bibliográfica e documental, descritiva e exploratória para o esclarecimento de elementos legais gerais para definição de conceitos filosóficos e jurídicos, com o intuito de levantamento de hipóteses reflexivas sobre a temática do cárcere brasileiro e seus problemas, especificamente o encarceramento feminino.

Palavras-chave: cárcere brasileiro; encarceramento feminino; epistemologia feminista; mulheres; vulnerabilidade.

\section{WOMEN AND PRISON:}

\section{AN ANALYSIS OF FEMALE INCARCERATION IN FRONT OF PERSONALITY RIGHTS VIOLATIONS} ABSTRACT

Faced with a scenario of invisibility, violence and neglect in which women in prison are inserted, the importance of studying the issue of female incarceration is brought up. The present work aims to promote reflections on the Brazilian female prison system, where it seeks to show, through history, women facing the punitive power, its process of criminalization and victimization from a gender perspective. Thus, it is of great importance that the analysis of the vulnerability of women in situations of prison takes place through a feminist epistemology and criminology committed to the vicissitudes of genders necessary in this environment of punishment. There is an indispensability to seek interventions that can improve the living conditions of this population through the implementation of specific public policies. Therefore, it uses hypothetical-deductive reasoning, through bibliographical and documentary, descriptive and exploratory research to clarify general legal elements for the definition of philosophical and legal concepts, in order to raise reflective hypotheses on the theme of prison and its problems, specifically female incarceration.

Keywords: Brazilian prison. Female incarceration. Feminist Epistemology. Women. Vulnerability. 


\section{INTRODUÇÃO}

Ser mulher parece ser também uma condenação a um "lugar" de inferioridade, menosprezo e de irracionalidade. Esse é o lugar precípuo que a construção social de gênero destina às mulheres. Não é necessário estar em uma prisão para saber disto, mas é na prisão que todos esses estereótipos sobre o feminino afloram como uma ferida purulenta e fétida, sem tratamento, que possa amenizar a dor de ser o que se é: uma mulher criminosa.

O cárcere sempre esteve presente ao longo de toda a história da humanidade, seja com a mesma finalidade ou não. Infelizmente, porém, essa temática ainda permanece periférica nos interesses da Academia e da sociedade em geral; talvez, por puro descuido ou por ser mais cômodo, posto que a prisão em nada se relaciona com nossas vivências do dia a dia. As pessoas que fazem parte dessa dinâmica acabam sendo esquecidas e as violações de direitos sofridas por elas tornam-se invisíveis. Do lado de fora, existe aquele que cobra, fere, abandona, estigmatiza e culpabiliza.

Busca-se trazer à tona essas diversas violações sofridas pelas mulheres encarceradas, dando ênfase àquelas que representam discriminações em razão do gênero. Uma análise de fácil constatação, tendo em vista a presença de diversos problemas e discriminações; problemas presentes desde a precariedade da estrutura física dos estabelecimentos até a desatenção aos cuidados básicos de saúde e pela impossibilidade de convivência sadia e adequada com os filhos. Para levantar essas questões sobre o encarceramento feminino, o presente estudo fará uma análise histórica da pena de prisão e modelos penal-penitenciários. Busca-se trazer a lume, por meio da história, as mulheres ante o poder punitivo e o processo de criminalização e vitimização destas, sob uma perspectiva de gênero por meio da compreensão de como, historicamente, o poder patriarcal e o poder punitivo articularam-se para sua custódia pelo Estado, pela família e na sociedade.

Para isso, será feita uma reconstrução, em termos gerais, da história do feminismo, realizando uma leitura dele como um processo revolucionário. A relevância deste escaneamento do movimento feminista, mediante a apresentação das formas pelas quais as mulheres conseguiam se apropriar de determinados momentos, nem sempre favoráveis, para se levantar contra o pensamento limitador vigente que coibia sua própria existência, é de demonstrar a importância de tal movimento não só para as mulheres, mas para todos os setores da sociedade anterior e atual.

Assim, ao refletir acerca das condições que envolvem o encarceramento feminino e analisar questões atinentes à dignidade da pessoa humana no sistema prisional brasileiro, aplicar-se-á o método científico hipotético-dedutivo a partir da confirmação ou refutação da hipótese inicial, procurando sempre levantar uma discussão fundamentada. Com base na técnica de pesquisa bibliográfica, procura-se explicar o encarceramento feminino, a seletividade penal e a reconstrução da origem das prisões e custódia da mulher ante o poder punitivo, desde referenciais teóricos, revisão de literatura de obras, artigos de periódicos e documentos eletrônicos oficiais. 


\section{RECONSTRUÇÃO HISTÓRICA DO FEMINISMO E A CUSTÓDIA DA MULHER}

Definir o termo feminismo não é uma tarefa fácil, apesar de a "origem" do vocábulo ser constatada em meados do século 19. A forma de pensar e agir, a ele associadas, não se restringem a esta parte da história, nem ao espaço geográfico em que foi registrado que, no caso, seria a Europa. Diversos estudiosos sobre a temática identificam o surgimento do feminismo na Inglaterra e na França, no final do século 18 e início do 19, atrelado às ideias de intelectuais, como a inglesa Mary Wollstonecraft (que elabora uma crítica ferrenha do sistema educacional que transmitia aos meninos os conhecimentos acumulados pela cultura ocidental e às meninas os conhecimentos ligados ao manejo do ambiente doméstico) e a francesa Olympe de Gauges (autora da Declaração dos Direitos da Mulher e da Cidadã, defensora dos direitos das mulheres na esfera política).

Vale reforçar, porém, que o entendimento das feministas contemporâneas ligadas aos estudos pós-coloniais e ao multiculturalismo têm críticas a esta definição, levam em consideração o fato de existir mulheres em várias partes do mundo e em contextos os mais variados, que lutaram e, ainda lutam, contra as formas de opressão a elas impostas. Assim, o feminismo teria genealogias múltiplas.

A autora Jussara Reis Prá leciona que feminismo se trata de um termo muito flexível, uma vez que compreende todo um processo de transformação $(1997$, p. 43). Tal processo tem raízes no passado e é ressignificado a cada nova geração de feministas, com seus desafios e contradições. De tal forma, dependendo do ponto de partida teórico, têm-se classificado diversos feminismos, ou melhor, vertentes de feminismos. Nesse sentido, Maria Gabriela Hita (2002, p. 324) ensina que "Existiram no passado e, ainda hoje, diferentes projetos, alguns até mesmo antagônicos, em função de premissas e imagens sustentadas sobre o ser humano, os gêneros e a sociedade em geral". Isso posto, em decorrência da existência de vários feminismos, com diversas perspectivas e características, pode-se aferir que o feminismo contemporâneo é fruto de inúmeras concepções que estiveram atreladas às demandas e às reivindicações necessárias de cada época.

Pode-se encontrar, então, o feminismo conservadorista, também chamado de feminismo burguês, que se preocupa com as tensões presentes nas relações entre as categorias de sexo derivadas da dominação exercida sobre a mulher, mas não questiona as origens político-culturais dessa desigualdade (SAFFIOTI, 1976, p. 105). Existe também o feminismo liberal; sua luta se dá no plano formal da lei, por acreditar no aperfeiçoamento progressivo dos dispositivos legais como forma de instituir a igualdade de direitos. Outro feminismo é o dogmático-marxista, inspirado nas obras de Marx e, sobretudo, Engels, quando todos os fenômenos sociais podem ser interpretados como lutas de classes e o problema da mulher seria parte dos problemas sociais gerais.

O feminismo radical, no entanto, trabalha com a ideia de patriarcado, um sistema de dominação dos homens sobre as mulheres em todas as esferas da sociedade. A família é vista como o local por excelência de uma psicologia do poder, servindo de base para hierarquizações e subjugações em todos os campos do social. Por fim, a socialista, baseado na dialética marxista "enquanto método que exige a formulação de novos conceitos adequados à análise de novas realidades, ou a reformulação de categorias conceituais inadequadas para uma 
análise conjunta dos dois fenômenos em pauta - classes sociais e categoria de sexo - e suas inter-relações" (SAFFIOTI, 1987, p. 113-114).

Algumas autoras acrescentam, ainda, o feminismo anarquista, que é contrário a todas as formas de hierarquia e à delegação de poderes; luta por "uma sociedade sem patrões, autoridades, religiões e preconceitos, onde as relações amorosas e sexuais seriam livres" (FERREIRA, 1996, p. 164); o feminismo, chamado de eco feminismo, é um termo originalmente usado pela francesa Françoise d'Eaubonne (1974) para se referir à luta ecológica/ambientalista aliada ao feminismo. Esse movimento busca o fim de todas as formas de opressão, incluindo a opressão ser humano-natureza, buscando um convívio sem dominante e dominado, em que há complementação e nunca exploração. Tem ainda algumas teorias que evidenciam o feminismo existencialista, que é o pautado nas ideias de Simone de Beauvoir e o feminismo da diferença, que parte do pressuposto de que as diferenças entre homens e mulheres não são o problema, mas a polarização e a hierarquização dessas diferenças por parte de quem as define.

O feminismo pode ser considerado, genericamente, uma teoria política e uma prática social que tem por objetivo compreender a origem da opressão das mulheres para, assim, pretender superar a condição de inferioridade que lhes foi imposta ao longo da história (PINTO, 2010, p. 15). A participação do movimento feminista em reivindicações, como a igualdade formal e econômica, a liberdade reprodutiva e sexual e o direito à diversidade sexual, racial e étnica, refletiu diretamente na elaboração de normas de proteção aos direitos humanos. Para Piovesan (2012, p. 7), essas reivindicações foram incorporadas pelos tratados internacionais de proteção aos direitos humanos e, ao se realizar um balanço das últimas décadas, constata-se que o movimento internacional de proteção aos direitos humanos das mulheres teve como foco três conteúdos centrais, que seriam: a discriminação da mulher, a violência contra a mulher e os direitos sexuais e reprodutivos.

A contribuição dos tratados internacionais de proteção a direitos humanos auxilia de forma expressiva na promoção das liberdades e no acesso às condições igualitárias de desenvolvimento social. De acordo com Amartya Sen, o desenvolvimento de muitos países está correlatamente ligado ao ganho de poder das mulheres, que transparece em fatores como a educação, seu padrão de propriedade, as oportunidades de emprego às quais elas têm acesso e o funcionamento do mercado de trabalho (2000, p. 235-236).

O pensamento feminista é de grande complexidade e de natureza fluida e interconectada (BRYSON, 2003, p. 2). Assim, o feminismo nada mais é do que a manifestação de propagação de igualdade, uma luta pelos direitos das mulheres por serem reconhecidas como sujeito de respeito, valor e dignidade. O termo feminismo foi cunhado, no ocidente, somente na segunda metade do século 19. O caminho percorrido para se chegar a fundar uma teoria feminista foi longo, decorrente de uma série de experiências históricas fundamentais para a constituição da primeira e da segunda onda do feminismo ${ }^{1}$.

É comum entender o feminismo como ondas, e recebem tal denominação por serem marcadores de época e terem características próprias. Vale mencionar, porém, que há ausência de um consenso em relação a esses marcos, aqui mantidos para efeito didático. 
Por mais paradoxal que pareça à primeira vista, pode-se observar uma receptividade e uma abertura muito interessantes para as mulheres na primeira fase do Cristianismo, apesar de a matéria religiosa estar sempre em primeiro plano (LEGATES, 2001, p. 27). No século 3은 - Cristianismo institui a castidade tanto para homens quanto para mulheres, e, apesar de essa condição ser aparentemente repressiva, as mulheres conseguiram beneficiar-se do pensamento cristão, buscando outras perspectivas para sua vida.

Esse período histórico era composto de baixa densidade demográfica, e a reprodução era uma necessidade fundamental na comunidade. A título de informação, LeGates aduz que, no fim do mundo romano, para que a população pudesse ser mantida, cada mulher deveria ter cerca de, pelo menos, cinco filhos (2001, p. 28). Assim, a maternidade parecia ser o destino de qualquer mulher, e muitas começaram a se apropriar dessas condições do início do Cristianismo e a divulgar a castidade para se insurgirem contra o que, por convenção, se esperava delas dentro da comunidade: o casamento e a maternidade.

Não é difícil imaginar que esse movimento começou a incomodar até mesmo dentro do próprio Cristianismo. Como consequência, essa abertura inicial foi reprimida, e, no século 5o, a estrutura da igreja era praticamente patriarcal. O que importa salientar neste momento é que a Idade Média foi um período em que, indubitavelmente, os homens tiveram o controle das escrituras e do saber. Apesar de as condições serem grandemente desfavoráveis para as mulheres, elas conseguiram elaborar linhas de fuga e construir alternativas às suas realidades. Os mosteiros passaram a ser um espaço interessante de autonomia para as mulheres que conseguissem percebê-lo (LEGATES, 2001, p. 32). A educação nos mosteiros era para ambos os sexos, e, lá, além do conhecimento da Bíblia, aprofundavam-se os estudos de direito canônico e direito civil. Além disso, muitas mulheres presentes nos mosteiros tinham conhecimento de artes, uma vez que esses lugares eram verdadeiros depositários de obras de arte (MENDES, 2017, p. 120).

Vale mencionar, ainda, o poder político e econômico que era viabilizado às mulheres a partir desses lugares. Tradicionalmente, os monastérios possuíam importantes pedaços de terra, o que os faziam ser, algumas vezes, grandes centros de administração, economia e política. Identifica-se uma oportunidade de tomada de poder das mulheres. Foi um momento histórico em que elas tinham poder para administrar cidades, recolher dinheiro e, em alguns casos, elas chegaram até a administrar comunidades tanto de monges quanto de freiras ao mesmo tempo (LEGATES, 2001, p. 33). No princípio da Idade Média, portanto, mulheres foram parar nos mosteiros, frutos de um processo espontâneo no início do Cristianismo, lugar em que encontraram, de início, as portas abertas. Muitas apropriaram-se da religião para ter alguma espécie de autonomia, e, por mais contraditório que pareça, conseguiram se beneficiar dos modelos femininos instituídos na época.

Com a baixa Idade Média, porém, os mosteiros, que antes eram espaços de formação intelectual para as mulheres, transformaram-se em verdadeiros cárceres, destinados à correição do que supostamente era considerado uma perversidade própria do sexo, segundo a medicina, a teologia e, até mesmo, o direito das épocas seguintes. Reforça-se o entendimento de Carla Casagrande (1990, p. 99), de que o final da Idade Média é um período paradigmático, quando se inicia um grande projeto destinado a descrever e classificar as mulheres para, en- 
fim, custodiá-las de todos os níveis. São diversos textos didáticos e pastorais produzidos nesse período dispostos a amoldar um critério unânime para etiquetar a categoria feminina.

A partir do século 12 e 13, pequenos grupos, com objetivos de renovar a cristandade e regressar aos valores apostólicos, como humildade, castidade e pobreza, pipocaram por toda a Europa (OPTIZ, 1990, p. 425), não sendo indicados e nem admitidos pela Igreja. Muitas muIheres, impulsionadas por esses grupos que percorriam os países, passaram a reunir-se em casas privadas ou cabanas nos arredores das cidades para ter uma vida simples, que lembrava a dos apóstolos de Cristo. Essas mulheres, que não eram controladas, passaram a ser vistas com maus olhos, consideradas prostitutas ou não puras, elevando-se a pressão da opinião pública e dos estamentos laicos contra a maneira de viver destas pessoas (OPTIZ, 1990, p. 425). Somente grupos que estavam instalados em casas fixas e tinham bens acumulados foram reconhecidos pela Igreja; os restantes viviam na mendicância.

Existiam muitas comunidades de mulheres interessadas em teologia até meados do século 13. Vários textos e tratados demonstravam grande conhecimento da Bíblia e novas visões para questões controversas, como o tratado de Marguerite Porète, considerada herege e que morreu queimada na fogueira em 1310 (LEGATES, 2001, p. 45), e os trabalhos de Hildegard de Bingen, Catherine de Siena e Birgitta da Suécia (OPTIZ, 1990, p. 426). Isso tudo provocava a desconfiança de muitos; experimentava-se uma cultura feminina desconhecida até então, por isso considerada perigosa. De acordo com Mendes (2017, p. 122), no século 13, com a entrada desses grupos mendicantes, a pregação encontra a força propulsora que precisava para fazer espalhar uma misoginia de ordem teológica nunca vista antes. Desenvolvia-se uma rede hierarquizada de relações feudais determinada por uma economia monetária e mercantil que, por sua vez, gestava novas culturas e formas de poder e erigia uma nova pedagogia para as mulheres, vistas como indivíduos predestinados ao mal.

Pensamentos de Aristóteles passam a ser revisitados por moralistas e pregadores, neste período da história, para justificar a necessidade de custodiar as mulheres. Para o filósofo, as mulheres eram seres frágeis, irracionais e passionais, incapazes de decidir assuntos públicos e sequer assuntos domésticos de maior complexidade (CASAGRANDE, 1990, p. 121). Os clérigos católicos, em sua maioria, pregavam a legitimidade exclusiva dos homens de falar a palavra de Deus. As mulheres passaram então a serem vistas como coisas e não mais como pessoas, sendo escondidas e vigiadas como um perigo iminente.

Quanto ao discurso jurídico medieval com relação às mulheres, importa realçar que tanto quando puramente canônico quanto influenciado pelo direito romano, sempre se constituiu como um dos pilares fundamentais da custódia feminina. De fato, vale relembrar que, mesmo com as invasões bárbaras e o declínio do Império Romano Ocidental, a influência romana não deixou de existir na Europa e a organização religiosa e administrativa se preservou (MARTINS, 2011, p. 210). Com o desenvolvimento do feudalismo nos séculos 10, 11 e 12, o direito ficou adstrito às regulamentações muito particulares, estabelecidas entre senhores e servos e, nesse período, é o direito canônico que se mantém como direito escrito e universal. Ressurge o direito romano no final do século 12 e início do 13, a partir da retomada do Corpus Juris Civilis de Justiniano (MARTINS, 2011, p. 211).

Um dos juristas da época que se destacou foi André Tiraqueau (1488-1558). Suas sentenças eram, para as mulheres, um catálogo de interdições de todas as formas (MENDES, 
2017, p. 137), que as proibia de ensinar e de falar a palavra de Deus; era um verdadeiro reflexo da ordem vigente. As divergências entre os juristas eram somente quanto aos fundamentos da pena que ia ser aplicada às mulheres. Em sua maioria, eram reprodutores dos discursos da época, em que mulheres eram vistas como impetuosas, frágeis, inconstantes e, por isso, não poderiam, de modo algum, ser juízas. Além disso, deviam respeito e obediência ao homem, por isso estavam juridicamente sob o poder do marido.

Com o descrito anteriormente, percebe-se a relevância de analisar as experiências históricas das mulheres no período medieval, o que leva à constatação da presença de uma herança medieval referente ao projeto de custódia que fortaleceu institucional e subterraneamente a existência de cárceres e a afirmação de que o gênero feminino constituiria um grupo perigoso. De acordo com Mendes, durante o período inquisitorial houve uma coordenação dos diversos ramos dos saberes (o teológico, o jurídico e o médico), e isso resultou em um discurso forte do poder punitivo em relação às mulheres, formando "[...] uma narrativa tão eloquente que durante muito tempo nada a pode suplantar" (MENDES, 2018). Assim, a ideologia em relação às mulheres sempre foi a de custodiar, de reprimir, de vigiar e encarcerar; isso tudo mediante mecanismos de exercício de poder tanto do Estado quanto da sociedade e da família.

Um outro ponto de análise sobre os movimentos e experiências históricas preparatórias das primeiras "ondas" do feminismo no ocidente ocorre em meio ao movimento filosófico do lluminismo e da Revolução Liberal, ou seja, séculos 17 e 18, apresentando, como base de pensamento, a premissa de que todos os seres humanos nascem livres e iguais, consequentemente com iguais direitos e deveres (ROUSSEAU, 1981, p. 192); isto é, a reivindicação do contrato social era a igualdade e a liberdade, consideradas inerentes a qualquer indivíduo. A liberdade e igualdade propagadas neste período, todavia, não se estendia às mulheres. Os iluministas carregavam as tradições liberais e reforçavam a dicotomia entre o feminino e o masculino incutida na sociedade como algo comum e passivo por todos, tendo em vista a herança trazida dos períodos históricos anteriores, ou seja, a mulher é um ser não dotado de razão e que atuava no espaço privado de forma limitada.

Os pensadores de destaque da área das ciências sociais, que justificaram a desigualdade mencionada, foram Locke (1632-1704) e Rousseau (1712-1778). É nesse momento que se prega a distinção entre sociedade política e sociedade conjugal-familiar, sendo atribuída a ideia de igualdade para a primeira e manutenção da tradição absolutista e patriarcal para a segunda, postulando pela sujeição natural da mulher ao homem. Ou seja, o contratualismo seria, por excelência, um mecanismo de controle social já dentro da atuação do poder constituído, uma forma de criar relações de subordinação e não de liberdade.

Desse modo, é notório que tal período da história foi favorável às críticas sociais. Nesse sentido, tentando reverter uma tradição que não era favorável às mulheres, muitas feministas instigaram-se com os ideais contratualistas e decidem utilizá-los, inspiradas em Locke (LEGATES, 2001, p. 121) e, mais tarde, orientando um caminho a partir de Rousseau. Assim, apesar das condições desfavoráveis, muito do que foi pensado nessa época auxiliou também na configuração do feminismo do século 19, quando se iniciam as ondas feministas.

As primeiras feministas ocidentais que apresentaram uma noção de mulher como uma coletividade, um grupo submetido a um aparato de dominação comum, foram as inglesas, 


\section{Democracia}

no final do século 17 e início do 18. Destaque especial merece a inglesa Mary Wollstonecraft, que, em 1792, publicou a obra "A vindication of the rights of woman", contestando bases patriarcais da época ao denunciar a exclusão de direitos inerentes às mulheres bem como o ser social presente no feminino (BICALHO, 2003, p. 38-39).

A produção francesa desse período sobre o tema das desigualdades entre os sexos ficou a cargo de Marie Jeanne Riccoboni (OLIVEIRA, 2007, p. 77). Outra francesa de destaque foi Olympe de Gouges, que, em 1791, escreveu a "Declaração dos Direitos da Mulher e da Cidadã", discutindo sobre o papel político feminino. A declaração era composta por 17 artigos (ASSMANN, 2018), vivenciando seu derradeiro combate contra a concepção de direitos universais do cidadão e denunciando a ausência das mulheres e a necessidade de que elas fossem contempladas legalmente.

Enfim, com todo o referencial teórico do período entre os séculos 17 e 18, é que o feminismo surge e se desenvolve com características de movimento de ruptura, contradição existente entre os princípios iluministas de igualdade universal e a exclusão das mulheres do acesso à plena cidadania. É importante mencionar, ainda, que, apesar das dificuldades teóricas ao longo das revoluções dessa época, existiram mulheres que, além de participarem ativamente dos processos revolucionários, também souberam se apropriar do tempo para apontar as singularidades dos mecanismos de poder aos quais estavam submetidas, como uma forma de poder constituinte (OLIVEIRA, 2007, p. 80).

Com a chegada do século 19 a formação do feminismo foi se intensificando de uma forma mais radical, tanto na teoria quanto no movimento. Então, a chamada primeira "onda" do feminismo se deu no transcorrer desse século, quando as mulheres, inicialmente na Inglater$\mathrm{ra}$, se organizaram para lutar por seus direitos. O primeiro destes direitos que se popularizou foi o voto (PINTO, 2010, p. 15). O movimento sufragista espalhou-se pela Europa e Estados Unidos (o movimento sufragista esteve inicialmente relacionado com o movimento Abolicionista). Procurava-se, então, incluir as mulheres no espaço público, quando sua atuação social se restringia ao mundo privado, doméstico.

O feminismo, pela primeira vez, é visto como movimento social de identidade autônoma teórica e organizativa, ocupando espaço de relevância nas discussões de caráter igualitário. As expectativas levantadas pela modernidade se contrastavam com a desigualdade social existente, e essas contradições foram essenciais para o desenvolvimento dos movimentos sociais e das teorias emancipatórias. Alguns destaques de pensadoras feministas, neste primeiro momento, são Flora Tristán (com a obra Promenades dans Londres) e Harriet Taylor (MERTON, 1970), que comungava das mesmas ideias de Mill, ou seja, participação no mercado de trabalho na sociedade capitalista e direito à propriedade dentro de uma sociedade democrática. Os discursos giravam em torno do direito das mulheres à educação, ao trabalho, e, ainda, questionavam-se as instituições políticas, a família e a própria sociedade (RUETHER, 1993, p. 180). Outros nomes de grande relevância foram das feministas Alexandra Kollontai e Virginia Woolf, que mantiveram o foco no direito ao voto feminino.

A primeira "onda", ou fase do feminismo, foi constituída de diversos movimentos sociais que ora se aproximavam ora se colidiam, de acordo com as condições específicas de cada local. Essa fase inicial restringiu-se, basicamente, à luta pelo voto das mulheres, não conseguindo conjugar de forma eficiente forças com as lutas referentes à classe e à raça. A segunda 
"onda" do feminismo tem como marco a década de 60 do século 20, e ganha destaque nos Estados Unidos e Europa. Foi uma fase marcada pelo espaço aberto que a mídia proporcionou à luta das mulheres que, inicialmente, além de manter pautas dos feminismos anteriores, tinha um caráter de libertação sexual e lutava pelo reconhecimento dos direitos reprodutivos, como os direitos à contracepção e ao aborto (ALVES, 2007, p. 52). Uma obra de grande influência nesse período e até hoje é $O$ segundo sexo, de Simone de Beauvoir, e é nela que a autora estabelece uma das máximas do feminismo: "não se nasce mulher, se torna mulher" (PINTO, 2010, p. 16).

Nesse ínterim, as primeiras manifestações do feminismo desse período buscavam tanto a recuperação do poder de procriação quanto a obtenção de uma nova liberdade sexual. É a partir da década de 60 do século 20 que se caracteriza uma intensa luta contra a discriminação racial, pelos direitos de minorias e reinvindicações estudantis (ALVES, 2007, p. 58). Amplia-se, dessa forma, o entendimento sobre o universo de possibilidades de formas de exercício de poder para além das estritamente econômicas. O movimento feminista passa a ser um verdadeiro movimento de massa que começa a se formar a partir da década 60 , com força política e potencial de transformação social; momento esse de grandes agitações sociopolíticas, como reação às contradições apresentadas pelo sistema, que têm sua legitimação na universalidade de seus princípios, mas que, na vida real, apresenta características sexista, racista e classista.

Assim, surgem, nessa época, até meados dos anos 1980, múltiplos movimentos sociais radicais, como os antirracistas, os movimentos estudantis, pacifistas e, principalmente, o feminista. Entre eles havia um liame que os conectavam: o caráter contrário à ordem cultural estabelecida (RUETHER, 1993, p. 187-189). Feministas importantes desse período trabalhavam em estudos que giravam em torno do patriarcado e política sexual. Entre elas estão Kate Millet ("Política sexual", 1970, nascendo, assim, a teoria feminista radical), Shulamit Firestone ("A dialética dos sexos", 1971) e Juliet Mitchell ("A condição da mulher", 1971 e "Psicanálise e feminismo", 1974). Insta salientar que ainda neste período se iniciam os estudos sobre gênero, passando o debate feminista a ser delineado com os contornos atualmente estudados.

\section{A QUESTÃO CARCERÁRIA NO BRASIL E O APRISIONAMENTO FEMININO}

É diante do aumento substancial da população carcerária feminina e do cenário de violações de direitos, que se verifica a real importância de se tratar da temática mulheres em situação de cárcere. Assim, se faz mister, inicialmente, promover reflexões sobre a questão carcerária no Brasil. Os presídios e cadeias públicas afiguram-se como depósitos humanos e palcos das maiores violações aos direitos fundamentais do homem. Na sentença penal não só há o cerceamento da liberdade do cidadão, mas de outros direitos essenciais também. $O$ direito à honra, privacidade, intimidade, liberdade sexual, saúde, educação, assistência jurídica, alimentação e vestuário digno, são os exemplos de direitos violados que parecem invisíveis aos olhos do poder estatal. A ressocialização no sistema prisional vigente é uma verdadeira e grande utopia.

Os relatórios do International Center for Prison Studies (ICPS) alertam há anos sobre o assustador aumento da população em situação de cárcere. Um relatório publicado em 2018, Word Prison Population List, pelo Institute for Criminal Policy Research (CIPR) expõe que mais de 10,74 milhões de pessoas estão presas por todo o mundo, tanto de maneira preventiva 
quanto já condenadas. O número pode ser ainda maior, pois falta contabilizar os presos de algumas jurisdições que não estão plenamente reconhecidas internacionalmente. De acordo com o relatório:

Desde o ano 2000, a população prisional mundial total cresceu quase $24 \%$, um pouco maior do que o aumento estimado da população geral do mundo durante o mesmo período. Há diferenças consideráveis entre os continentes, com variações dentro deles. A população presa na Oceania aumentou em quase $86 \%$, e nas Américas em $41 \%$; na Ásia em $38 \%$ e na África em $29 \%$, na Europa, por outro lado, a população carcerária total diminuiu em $22 \%$. O número europeu reflete quedas na população prisional na Rússia (45\%) e na Europa Central e Oriental; a população carcerária na Europa, exceto a Rússia, aumentou 3\%. Aumentos particularmente grandes foram registrados na América do Sul (175\%) e no Sudeste Asiático (122\%) (CIPR, 2018, p. 2, tradução nossa).

De fato, os números são alarmantes. O fenômeno do encarceramento em massa apresenta diversas consequências que, apoiado no prisma da proteção efetiva dos direitos humanos, aponta para danos graves e tendências político penais perigosas (BEIRAS, 2019, p. 49).

Segundo a reflexão de Elías Carranza (2012), existem duas respostas que podem ser adotadas quando for questionado o motivo do aumento gigantesco da população presa:

Duas respostas clássicas foram dadas à essa pergunta: i) Porque há mais delito. Esta resposta considera as taxas penitenciárias como indicadores de criminalidade; e ii) Porque há políticas que promovem maior uso da justiça penal e da prisão. Esta resposta inclui o resultado de pesquisas que verificam que nem sempre existe correlação entre o aumento das taxas penitenciárias e as taxas de criminalidade, observando-se casos em que a população prisional aumenta paralelamente as taxas de criminalidade planas ou mesmo decrescentes. No caso dos países da América Latina e do Caribe, o ILANUD verificou que (...) as políticas de maior uso e maior severidade da justiça criminal prevalecem na maioria dos países (p. 37).

A contemporânea crise econômica favorece para afigurar os contornos do Estado penal máximo, cujo investimento em políticas penais extremamente punitivistas é alto. Assim, para essa lógica, é mais "viável" apostar nestas políticas penais do que em outras de ordem social, que buscam traçar rotas alternativas à prisão com medidas restaurativas, comunitárias ou médico-assistenciais, as quais, de acordo com Beiras (2019, p. 55), "iniciavam com a manutenção dos infratores na comunidade-sociedade-território e, em última instância, na prisão, e hoje são modelos tão abandonados que parecem desconhecidos para a própria comunidade científica".

Conforme as reflexões teóricas de Iñaki Rivera Beiras (2019, p. 53-54), as consequências do fenômeno do encarceramento em massa são diversas e causam danos sociais generalizados e difusos. De um lado, a superlotação dos cárceres em colapso coloca em xeque os direitos fundamentais dos indivíduos presos e violações de recomendações e tratados internacionais, como as Regras Mínimas para o Tratamento dos Reclusos da ONU de 1955 e 2015 e a Convenção contra a Tortura e Outras Penas ou Tratamentos Cruéis, Desumanos ou Degradantes da ONU de 1984. De outro lado, os danos sofridos citados também refletem em outros grupos de indivíduos. Nas palavras do autor: 
Os danos acima mencionados também são projetados em outros grupos de pessoas afetadas, especialmente sobre as famílias e ambientes sociais das pessoas presas, não menos prejudicadas que estas em uma série de questões essenciais de caráter pessoal, afetivo, laboral, econômico, assistencial. E são muito especialmente as mulheres que sofrem em suas vidas cotidianas a ausência de maridos, filhos e pais em privação de liberdade, danos cujo exame requer uma especial perspectiva de gênero em sua consideração. Da mesma forma, os próprios trabalhadores penitenciários (funcionários regimentais, de tratamento, de atenção à saúde e à educação e de gestão administrativa) internalizam e também sofrem os efeitos negativos da segregação prisional em massa, com importantes índices de distúrbios emocionais, psicológicos [...] (BEIRAS, 2019, p. 53-54).

Encarceramento em massa afeta a sociedade como um todo. Há um grande dano social causado gerado por opções punitivas de alto custo econômico, cultural e político-social. Isso decorre porque contribui para maximizar ainda mais a vulnerabilidade de muitos setores sociais. O cárcere segue ocupando posição central no sistema formal de controle, e seus números são muito significativos, revelando a potência crescente de uma política criminal hostil e excludente, marcada, sobretudo, pela seletividade e pela negação de direitos a parcelas mais vulneráveis da população - a juventude negra e pobre - que é a que mais sofre a seletividade genocida das agências punitivas brasileiras (CARVALHO, 2010, p. 143).

Em terras brasileiras a realidade é a mesma. Encarcera-se cada vez mais indivíduos jovens, pobres e com baixa escolaridade. O Brasil é o terceiro país com mais pessoas em situação de cárcere do mundo. São cerca de 726.354 pessoas privadas de liberdade (BRASIL, 2017a), ficando abaixo apenas dos Estados Unidos e China. Há um grande afastamento entre a mens legis e a realidade do sistema carcerário nacional, e isso é decorrente da ausência de vontade política por parte do próprio Estado em tutelar uma minoria impopular (SANTOS; ÁVILA, 2017, p. 270). No âmbito constitucional, a dignidade da pessoa humana, consagrada no artigo 1으, inciso III, demarca um campo de padrão mínimo na esfera dos direitos sociais, e isso evidencia que a falta de condições materiais mínimas ao homem retira da pessoa o seu desenvolvimento físico e psíquico, gerando muita injustiça.

Além do princípio basilar da dignidade humana, há 32 disposições, só no artigo 5o, destinadas à proteção, direta ou indireta, das garantias da pessoa privada de liberdade. Um agrupamento de normas que revela um compromisso aparente do Estado. No âmbito infraconstitucional, o descompasso entre norma e realidade pode ser facilmente observado ao tomar como parâmetro a Lei de Execuções Penais, que encampa rol extenso de direitos e deveres do preso, objetivando a humanização do cumprimento da pena. Ainda, a situação degradante da prisão brasileira já foi amplamente explorada e está descrita em diversos relatórios de organizações nacionais e internacionais que monitoram as violações de direitos humanos no sistema carcerário, além de estar amplamente estampada em todos os dados oficiais do governo brasileiro, que não deixam dúvidas sobre a insuficiência das políticas públicas voltadas ao cárcere até então desenvolvidas.

Documentos internacionais dos quais o Brasil é signatário também revitalizam a necessidade de proteger a pessoa encarcerada, como a Declaração Universal dos Direitos Humanos, a Declaração Americana de Direitos e Deveres do Homem, a Resolução da ONU e as Regras de Bangkok, que foram aprovadas em 2010 pela Assembleia Geral das Nações Unidas, que é um importante documento internacional, em que são reafirmados direitos humanos 
relativos à maternidade, à família, à saúde da mulher, inclusive sexual e reprodutiva, e de seus filhos no cárcere, e a Conferência Internacional da ONU sobre População e Desenvolvimento, realizada no Cairo, Egito.

Apesar de ser um quadro de previsões constitucionais, infraconstitucionais e documentos internacionais que prevê direitos e regras mínimas de tratamentos de pessoas em situação de cárcere, ainda verifica-se um quadro de violação massiva a direitos fundamentais e a grande falência de políticas públicas envoltas de uma cultura punitiva, em que está inserido o desejo de maior hipertrofia do sistema penal como resposta aos riscos da atualidade.

O Sistema Integrado de Informações Penitenciárias (Infopen) será uma ferramenta fundamental e servirá como ponto de partida e base para este estudo. Esse sistema é um programa (software) de coleta de dados do Sistema Penitenciário alimentado pelos próprios Estados, e os dados, consolidados pelo Departamento Penitenciário Nacional, vinculado ao Ministério da Justiça, fornecem um retrato sobre a estrutura do sistema penitenciário e um perfil dos presos e presas custodiados pelo Estado².

Os dados trazidos pelo Infopen demonstram que o número de pessoas presas cresceu 707\% em relação ao total registrado no início da década de 90 do século 20 (BRASIL, 2017a). Com relação à população carcerária feminina, o aumento exponencial chega a $656 \%$ em relação ao total registrado no início dos anos 2000, enquanto na masculina o porcentual foi de $293 \%$ no mesmo período (BRASIL, 2017b). Reforça-se que, apesar da representação numericamente inferior de mulheres no sistema prisional em relação ao cárcere masculino, o aumento do encarceramento feminino é alarmante. $O$ fato de o número de mulheres presas ser inferior ao número de presos, é utilizado para justificar a secundarização das necessidades específicas e para a quase inexistência política penitenciária que atenda o gênero feminino. Segundo o Infopen, cerca de $74 \%$ das unidades prisionais destinam-se aos homens, somente $7 \%$ ao público feminino e outros $17 \%$ são caracterizados como mistos (BRASIL, 2017b).

As análises do crescente encarceramento das mulheres femininas orientadas por perspectivas de gênero, irão possibilitar uma compreensão por meio de novos pontos de vista sobre a seletividade penal e de quais maneiras operam os mecanismos de controle que encarceram parcela das mulheres e as subordinam às condições de criminosas (CARVALHO; MAYORGA, 2017, p. 102). O sistema penal ainda atua sob a mesma ótica, reproduzindo a concepção seletiva que o orientou desde o século 16, ou seja, existe uma desproporção entre a programação legal do sistema penal (inflação legislativa penal característica da maximização e ampliação sem precedentes do sistema penal) e a capacidade operacional das agências de controle para perseguir e punir os agentes que cometem as condutas definidas como crime e que é muito inferior ao universo de crimes praticados (ZAFFARONI, 1991, p. 26).

Andrade (2003, p. 48) trabalha sobre a seletividade do sistema penal. Segundo a autora, essa seletividade se deve,

\footnotetext{
É importante reportar que Ministério da Justiça têm como fundamento as informações prestadas pelos Estados, e isso, eventualmente, pode gerar algumas inconsistências e comprometer as análises que se faça a partir deles, pois não há um padrão ou controle rígido no preenchimento do formulário. Apesar das inconsistências, esse programa permanece sendo uma compilação de dados oficiais existentes disponibilizada pelo Estado.
} 
Em primeiro lugar, à incapacidade estrutural de o sistema penal operacionalizar, através das agências policial e judicial, toda a programação da Lei penal, dada a magnitude da sua abrangência, pois está integralmente dedicado a administrar uma reduzidíssima porcentagem das infrações, seguramente inferior a $10 \%$. Por outro lado, se o sistema penal concretizasse o poder criminalizante programado provocaria uma catástrofe social. [...] E diante da absurda suposição - absolutamente indesejável - de criminalizar reiteradamente toda a população, torna-se óbvio que o sistema penal está estruturalmente montado para que a legalidade processual não opere em toda sua extensão. $O$ que significa que não adianta inflacionar o input do sistema, através da criação de novas leis porque há um limite estrutural ao nível do out pui.

Os dados atuais mostram que a maioria dos detentos do presente sistema penitenciário brasileiro é oriunda da parcela mais vulnerável da população, e a atuação seletiva do sistema de justiça penal ocasiona muitas violações e institui uma forma paradoxal de enfrentar a criminalidade (ANDRECIOLI; SIQUEIRA, 2019, p. 12).

A operacionalização do cárcere, portanto, é extremamente funcional ao selecionar a população que se encontra na margem social. O que se visualiza é um sistema penal que se configura como uma instância do controle social, que nada mais é do que uma contínua seleção e reprodução das relações de desigualdade de produção, em conjunto com outras formas de controle social formal e informal (ÁVILA, 2013, p. 206). A função real e a lógica estrutural de funcionamento do sistema de justiça criminal estão calcadas na seletividade penal. Nas sociedades patriarcais e capitalistas, o que mais evidencia essa seletividade é a própria clientela da prisão, ao revelar que a construção simbólica e instrumental da criminalidade incide estigmatizantemente sobre a pobreza e a exclusão social (ANDRADE, 2007, p. 81).

Como alude Andrade (2007, p. 89), o sistema de justiça criminal funciona como um mecanismo público integrativo do controle informal dirigido à mulher, reforçando o controle patriarcal, a estrutura e o simbolismo de gênero, ao criminalizar a mulher em algumas situações específicas e, principalmente, por reconduzi-la ao lugar de vítima, ou seja, "mantendo a coisa em seu lugar passivo". Dessa maneira, compreender o aumento do aprisionamento feminino por intermédio da perspectiva de gênero irá permitir o entendimento sobre os imperativos de seletividade do sistema criminal; sistema esse que obscurece processos histórico-sociais que contribuem para o encarceramento de certa parcela de mulheres.

A compreensão sobre a temática das mulheres em situação de cárcere deve perpassar pela análise da exclusão das mulheres como sujeito e objeto de conhecimento, em especial nas discussões de cunho criminológico e de política criminal. É importante colocar a produção do saber em questão para que se possa repensar por que determinados fatores se tornam objetos de pesquisa, enquanto outros permanecem em completo silêncio, além de diversificar o olhar sobre fenômenos antes ignorados ou pensados apenas sob a lógica androcêntrica e generalizantes. A existência da relação entre a criação do conhecimento e as formas de poder em determinada sociedade é objeto de diversas reflexões, e a junção do saber e do poder cria discursos e práticas que causam impactos diretos na vida das pessoas (ANDRECIOLI; SIQUEIRA, 2019, p. 15).

As formas de dominação simbólicas e violentas acarretam quadros de opressão e silenciamento, principalmente no que se refere à mulher. De acordo com Bourdieu (2012, p. 45), os privilégios do masculino e a consequente submissão do feminino não se sustentam apenas 
pela violência física, mas, muito antes, pela violência simbólica repassada pelas vias do conhecimento e da comunicação, que é absorvida tanto pelos algozes quanto pelas vítimas.

O sociólogo francês Bourdieu leciona que a violência simbólica representa uma forma de violência invisível que se impõe numa relação do tipo subjugação-submissão, cujo reconhecimento e cumplicidade fazem dela uma violência silenciosa que se manifesta sutilmente nas relações sociais e resulta de uma dominação, sendo muito difícil escapar desta dominação simbólica; o dominado é cúmplice, dado o estado natural em que a realidade se apresenta (BOURDIEU, 2012, p. 7-8).

Assim, o pensamento feminista introduziu uma ética que se distingue da tradicionalmente estabelecida na ciência moderna. Essa ética feminista constitui-se a partir de seres humanos reais em condições de dominação e subordinação. Desse modo, "Essa ética traz o questionamento e uma tomada de consciência em torno da especificidade da mulher, de sua condição de exploração, de discriminação, de alienação, de exclusão, etc. Elementos esses que constituem e possibilitam um saber inovador" (BANDEIRA; SIQUEIRA, 1997, p. 270).

A epistemologia feminista considera as teorias dominantes "unidimensionais e profundamente falhas, em razão da exclusão e da representação incorreta das contribuições das mulheres", e um aspecto importante de seu programa tem sido "minar a imagem abstrata, racionalista e universal da teoria científica" (NARAYAN, 1997, p. 277). A autora adverte, ainda, que a epistemologia feminista sugere uma integração das mulheres à produção da ciência e do conhecimento, com uma maior participação das mulheres e uma mudança na própria natureza dessas atividades e sua autocompreensão. Talvez possa ser estranho aos ouvidos tratar de temas de justiça criminal e encarceramento sob perspectiva feminista; afinal de contas, normalmente se tem um ideário de que o feminismo trata somente daquelas reinvindicações dos movimentos sociais. Na verdade, porém, a perspectiva feminista deve ser encarada como uma perspectiva teórica, e o feminismo também é uma teoria crítica que busca apontar as lacunas que existem nos estudos realizados nas mais diversas áreas, que acabam deixando de considerar aspectos fundamentais que dizem respeito às mulheres.

Ora, nesse sentido, a perspectiva feminista de produção de conhecimento parte das experiências concretas das mulheres. Todas as mulheres têm experiências em relação a tudo na vida, como a questão da maternidade, quanto ao mercado de trabalho, dentro da academia e como atrizes do sistema de justiça criminal. Essas experiências devem ser levadas em consideração nos estudos epistemológicos e criminológicos.

É interessante trazer a ideia da obra "Um teto todo seu", de Virginia Woolf (1985), que, no século 20, já apresentava reflexões sobre as dificuldades que as mulheres encaravam no seu tempo como escritoras e produtoras do conhecimento. A obra de Woolf foi lançada em 1929 e é oriunda de reflexões de uma série de palestras proferidas pela autora nas faculdades em que as mulheres podiam estudar. Nessas palestras, Woolf levantava um questionamento importante para as estudantes: $O$ que é que falta para as mulheres para que haja o reconhecimento e que tenham as mesmas condições dos homens escritores? Woolf (1985) considerava que o que faltava eram recursos e investimentos financeiros nas mulheres. Com isso, ela identifica a inexistência, seja física, econômica ou social, de um espaço para as mulheres, de um lugar em que elas pudessem, com liberdade e tranquilidade, livre das amarras que são impostas até hoje, escrever e produzir conhecimento. 
Assim, para a autora, justamente por ser mulher, não se encontra reconhecimento na literatura tal qual existe para os homens. $\mathrm{O}$ que Woolf retrata é ainda uma realidade no âmbito das ciências criminais. $\mathrm{O}$ feminismo, portanto, foi essencial para apontar a possibilidade de criação de novos discursos e de novas realidades para as mulheres que, antes, eram relegadas a um cenário secundário, e fez emergir outro sujeito coletivo monumental, criando uma nova narrativa, resinificando a relação entre a narrativa promovida pelo saber masculino onipresente e o silêncio histórico feminino. O feminismo mostra-se como uma nova área em diversos campos do conhecimento, especialmente na criminologia, que possuía, até então, seu universo centrado no masculino (ANDRADE, 2012, p. 127).

É importante mencionar que uma das grandes contribuições dos estudos de gênero e do feminismo foi a introdução de um modo diferente de fazer ciência, na qual a experiência e a posição do sujeito em seu contexto se constituem como elementos significativos. Como leciona com Machado (2013, p. 125), os estudos de gênero e as indagações sobre as epistemologias feministas instituíram um estilo que deu maior espaço à reflexão sobre a subjetividade do/a autor/a e, também, da construção das subjetividades dos sujeitos sociais.

O gênero é uma ferramenta conceitual que permite compreender como se produzem, em nossa sociedade, as relações de exploração, de dominação e de violência, bem como as hierarquias desiguais de gênero. Conforme Machado (2015, p. 355) aduz, gênero, como categoria analítica abordada nos estudos feministas, tem a funcionalidade de iluminar as diferentes posições ocupadas por homens e mulheres, destacando o modo como as diferenças construídas socialmente resultam em critérios de distribuição de poder e das relações de subordinação.

Impactos concretos em diversos setores que a população feminina ocupa são gerados a partir da exclusão das mulheres do ponto de vista da criação do saber. $\mathrm{O}$ espaço prisional feminino é um exemplo dos impactos que essa exclusão ocasiona; isso impossibilita a formulação de soluções coerentes para os problemas que vêm sendo postos, como a questão da maternidade no cárcere, direitos sexuais e diversas outras violações recorrentes nesse ambiente. Com o aumento alarmante da população carcerária feminina, resta evidente a necessidade da reflexão sobre as causas e consequências de maneira que se valorize e se exponham as vicissitudes de gênero envolvidas.

Ainda é restrita a aplicação do conhecimento acumulado da Criminologia Feminista em busca da compreensão dos fenômenos relacionados ao encarceramento feminino e na minimização dos fatores que nos levam a essa realidade. Além do mais, muitas pesquisas na área criminológica feminista pecam ao não aplicarem uma epistemologia condizente e utilizarem chaves de pensamento próprias de um discurso totalizantes que exclui as mulheres. $\mathrm{Na}$ atualidade, a omissão de formulações e cuidados referentes às mulheres encarceradas está distante de ser apenas uma questão de peso demográfico. A disparidade marca a própria assimetria que se evidencia no debate impregnado pela lógica da dominação simbólica masculina (CUNHA, 2007, p. 82).

Em uma constatação histórica sobre a temática prisões, observa-se como a reclusão masculina sempre estabeleceu parâmetros dessa discussão. A criminologia nasceu como discurso de homens para homens e, no decorrer temporal, se transformou em um discurso de homens, para homens e sobre homens, de forma que, no discurso criminológico competente 
atual, a mulher surge somente em alguns momentos, como uma variável, jamais como um sujeito (MENDES, 2017, p. 157). A prova de que pouco ou nada dizem os processos de produção do conhecimento no campo das ciências criminais com relação às mulheres como sujeitos de realidades históricas, sociais, econômicas e culturais, é que, desde os tempos antigos até a atualidade, as formulações referentes a mulheres, geralmente, limitam-se a repetir noções religiosas e de senso comum. São poucas as pesquisas que fazem uma análise pormenorizada a respeito das especificidades de mulheres autoras ou vítimas de delitos que não reproduzam preconceitos arraigados do imaginário social (ANDRECIOLI; SIQUEIRA, 2019, p. 17).

Segundo Zaffaroni (1995, p. 23-28), a obra Malleus Malleficarum (Martelo das Feiticeiras) é um marco criminológico, tendo em vista que foi a primeira vez que se desenvolveu um discurso refinado de criminologia etiológica, direito penal e processual penal. A Inquisição foi uma manifestação orgânica do poder punitivo recém-nascido. A obra Martelo das Feiticeiras foi uma compilação de crenças na alardeada propensão da mulher ao delito, um manual de inquisidores em que se estabelece uma relação direta entre a feiticeira e a mulher, a partir de partes do Antigo Testamento, Antiguidade Clássica e de autores do medievo. Conforme leciona Anitua (2008, p. 57), é a partir desse ideário que o poder punitivo se materializa de modo a reforçar seu poder burocrático e reprimir a dissidência, em especial, às mulheres.

A caça às bruxas é um elemento histórico marcante de prática misógina de perseguição. O empreendimento ideológico foi muito bem arquitetado e alicerçado, e, depois do Mellus Maleficarum até o século 19, a criminologia, salvo algumas referências esporádicas, não mais se ocupou das mulheres (MENDES, 2017, p. 29). No contexto da criminologia moderna, a Escola Positiva caracterizou-se pelo uso do método experimental, e Cesare Lombroso foi o grande expoente da antropologia criminal nesse período. Para ele, o objeto a ser pesquisado não era o delito e, sim, o delinquente, sendo a pena definida como meio de defesa social, proporcional à periculosidade do criminoso.

Em 1892, Lombroso e Giovanni Ferrero lançam a obra La Donna Delinquente, em que se aplica às mulheres os estudos que ele havia realizado com os homens. Respaldando-se na cientificidade das teorias biologicistas, os autores contribuíram com a sistematização dos estigmas femininos, classificando as delinquentes em categorias: criminosas natas, criminosas ocasionais, ofensoras histéricas, criminosas de paixão, suicidas, mulheres criminosas lunáticas, epilépticas e/ou moralmente insanas (MENDES, 2017, p. 43). Nesse seguimento, Anitua (2008, p. 306) assevera que Lombroso se volta para as ideias inquisitoriais da inferioridade das mulheres para cometer delitos, destacando características como a extrema perversidade, a sexualidade exacerbada, a lascívia e o caráter vingativo. Rafael Garófalo, discípulo de Lombroso, confere relevância ao fator psicológico para o estudo da criminologia ao atribuir a tendência ao crime a um tipo de anomalia moral, que podia ser curável ou incurável (KOLKER, 2004, p. 178).

Tanto com relação ao Martelo das Feiticeiras quanto às formulações de Cesare Lombroso, para além de contribuírem para a consolidação de uma estereotipia feminina, muito pouco se desenvolveu com relação ao papel da mulher como autora de delitos. Na atualidade, ainda é facilmente perceptível que as mulheres que cometem crimes seguem sendo mais punidas pelo sistema e pela sociedade, e suas histórias mantêm-se emudecidas. É por meio de condições como essas que se verifica a necessidade de uma epistemologia feminista que não 
venha a escorregar em discursos criminológicos masculinos, que, aparentemente, se dirigem a todos os indivíduos (ANDRECIOLI; SIQUEIRA, 2019, p. 18).

Vale ainda trazer, mesmo que brevemente, a contraposição das Teorias Clássicas de viés psicobiológico de predisposições inatas para a ação criminosa, que fica a cargo de Emile Durkheim e Merton. O primeiro desenvolve uma teoria que considerava o crime como um fenômeno sociológico, inerente ao funcionamento de qualquer sociedade, não podendo atribuir a um indivíduo em particular (BATITUCCI, 1999, p. 12). Já, no século 20, Merton (1970), estudando a criminalidade, propôs o estado de anomia social como explicação do desvio. Logo, para Merton (1970, p. 205-209), o comportamento desviante é visto como normal, e, como apenas alguns indivíduos são pressionados à transgressão, a explicação biológica perde o seu sentido, uma vez que todos os homens possuem os mesmos instintos básicos. O que ocorre é uma incompatibilidade entre os objetivos prescritos culturalmente, e os meios institucionais legítimos para a realização dessas aspirações implicariam uma situação de anomia, podendo decorrer em atos criminosos.

Assim, o autor trabalha com a ideia de uma situação de equilíbrio entre dois elementos da estrutura social (metas/objetivos e normas) quando as satisfações proporcionadas aos indivíduos se ajustam de um lado às pressões para alcançar metas valorizadas e, de outro, às formas aceitas para atingir o objetivo. Em síntese, a extrema ênfase no sucesso com sinônimo de acumulação de riqueza em oposição ao limitado acesso aos modos institucionalizados de se adquirir fortuna, poderia maximizar a busca de recursos ilegais para o alcance de objetivos socialmente valorizados (BATITUCCI, 1999, p. 18).

A conexão entre desvio e pobreza sofreu críticas no âmbito da Sociologia Criminal, porém foi muito importante na ampliação dos debates, estimulando desdobramentos teóricos para a compreensão do fenômeno da criminalidade. Há muito a ser desenvolvido e empiricamente estudado em relação à criminalidade, principalmente a feminina. De acordo com Mendes (2017, p. 14), o reconhecimento de um referencial autônomo que permita compreender os diferentes contextos de vitimização e criminalização das mulheres é extremamente necessário, ou seja, um referencial epistemológico que, sem abrir mão da crítica ao direito penal, trabalhe e reconheça esse processo de criminalização do feminino sob a perspectiva de gênero.

Atualmente, ainda há uma herança das perspectivas criminológicas e cientificistas clássicas e positivistas. É muito comum o pensamento maculado de explicação do encarceramento feminino por meio de definições estereotipadas sobre o perfil das mulheres criminosas. Reproduzem-se discursos de exclusão e controle para aquelas que, historicamente, foram silenciadas e marginalizadas (ANDRECIOLI; SIQUEIRA, 2019, p. 17). Vale mencionar que o primeiro momento criminologia foi quando o positivismo e a violência institucional individual cederam espaço a uma criminologia do sistema de justiça criminal. O segundo salto ocorre na década de 70 do século 20, quando o desenvolvimento materialista da criminologia migrou para a chamada criminologia radical, nova criminologia e criminologia crítica.

O surgimento da criminologia crítica teve como grande destaque a obra "Punição e estrutura social", de George Rusche e Otto Kirchheimer. Apesar de o trabalho ser escrito entre 1938 e 1939, a leitura só ocorreu nos anos 1970. A obra traz a demonstração do caráter histórico dos sistemas penais por meio das suas diversidades com relação às diferentes fases do 


\section{Democracia}

processo de acumulação de capitais, trazendo a reflexão sobre as mudanças oriundas de um processo de duração entre os séculos 15 e 20 (BATISTA, 2011, p. 91).

Rusche e Kirchheimer (2004, p. 31-40) anunciavam que os diversos sistemas penais estavam diretamente relacionados às fases do desenvolvimento econômico e, em decorrência disso, com a formação do Estado Moderno, a prisão torna-se uma grande necessidade do capitalismo industrial. Conforme expõe Vera Malaguti Batista (2011, p. 91-96), George Rusche foi o primeiro pensador marxista a sistematizar as relações entre mercado de trabalho, sistemas penais e condições sociais, e seu trabalho, juntamente com "Vigiar e punir" de Foucault (2007), fomentaram a grande ruptura epistemológica que balançou as militâncias e teorias criminológicas na Europa, América Latina, Canadá e nos Estados Unidos. A partir da década de 80 do século 20, de acordo com Mendes (2017, p. 62-63), a criminologia, sob um direcionamento crítico, passa a interpretar o sistema de justiça criminal sob um viés feminista e macrossociológico de acordo com as categorias do patriarcado e do gênero que mostra como o sistema de justiça criminal trata a mulher.

Um dos exemplos de estudos promovidos com o desenvolvimento feminista da criminologia crítica é com relação à analise teórica e empírica do funcionamento do sistema de justiça criminal relativo à violência sexual, abordado por Andrade (2007). Conforme a autora, "O sistema não apenas é estruturalmente incapaz de oferecer alguma proteção à mulher, como a única resposta que está capacitado a acionar - o castigo - é desigualmente distribuído e não cumpre as funções preventivas (intimidatória e reabilitadora) que se lhe atribui. Nesta crítica se sintetizam o que denomino de incapacidades protetora, preventiva e resolutória do SJC" (ANDRADE, 2007, p. 57). A conclusão a que a autora chega ao final de sua reflexão é de que o sistema de justiça criminal atua como um mecanismo público integrativo de controle informal direcionado às mulheres, que corrobora o controle patriarcal ao criminalizar a mulher em alguns casos específicos e, principalmente, ao reconduzi-la ao lugar de vítima (ANDRADE, 2007, p. 66).

Isso posto, verifica-se que é por meio de um paradigma feminista, que permite identificar mais facilmente os discursos totalizantes que acabam por excluir o feminino de suas reflexões, que se dará voz àquelas que são historicamente silenciadas. Como, portanto, leciona Mendes (2017, p. 158), adotar um paradigma feminista significa "um giro epistemológico, que exige partir de uma realidade vivida pelas mulheres (sejam vítimas, rés ou condenadas) dentro e fora do sistema de justiça criminal". É nesse sentido que uma análise crítica das instituições prisionais de mulheres, baseada em um ponto de vista feminista, pode contribuir para uma compreensão mais imparcial das prisões contemporâneas, possibilitando reformulações no quadro teórico dos estudos prisionais, bem como possibilitando um debate rico sobre reclusão, exclusão e controle social (CARVALHO; MAYORGA, 2017, p. 107).

Segundo Alessandro Baratta (1999, p. 23-39), a utilização do paradigma de gênero é uma condição necessária para o sucesso da luta emancipatória da mulher no universo da ciência e da política do direito. Acrescenta o autor que a criminologia feminista só poderá se desenvolver, de modo oportuno, sob o viés epistemológico da criminologia crítica. Mendes (2017, p. 163) vai além, ao afirmar que a "criminologia crítica somente poderá sobreviver na perspectiva epistemológica de uma criminologia feminista". Dessa forma, a teoria feminista é uma teoria sobre a sociedade desde as experiências de mulheres. A partir desse 
pressuposto, é mister a aplicação do paradigma feminista comprometido com a situação de vulnerabilidade das mulheres em situação de cárcere, quando se visa à compreensão do controle e seletividade configuradores do sistema penal, sistema este que encobre processos histórico-sociais que contribuem para o aprisionamento de específica parcela das mulheres. É por intermédio desse referencial teórico que se verificará uma abertura para intervenções que possam melhorar as condições de vida das mulheres no cárcere e também fora dele.

\section{CONSIDERAÇÕES FINAIS}

O problema do presente estudo consistia em dar visibilidade a uma parcela da sociedade muito estigmatizada, esquecida e em situação de extrema vulnerabilidade: as mulheres encarceradas pelo sistema prisional brasileiro. Buscou-se, assim, ir além dos muros penitenciários para se compreender o aprisionamento feminino, tendo em vista que a grande parte das mulheres em situação de cárcere vive em um cenário de descaso.

Em um cenário conclusivo, após a reconstrução da história do feminismo, constatou-se que os movimentos de mulheres são movimentos não clássicos, na medida em que transcorrem nas esferas não tradicionais de organização e ação política. Com o feminismo evidenciou-se a complexidade da dinâmica social e da ação dos sujeitos sociais, revelando o caráter multidimensional e hierárquico das relações sociais, além da existência de uma grande heterogeneidade de campos de conflito.

O que se pretendeu fazer, então, foi uma leitura da trajetória do feminismo, apresentando as formas pelas quais as mulheres conseguiam se apropriar de determinados momentos históricos, na maioria das vezes não favoráveis para questionar o pensamento vigente, seus direitos e sua própria existência como membro da sociedade. Isso posto, construiu-se um diálogo com a história do feminismo procurando identificar, em suas estratégias e reivindicações, os elementos que unificam a luta das mulheres com um processo de transformação das relações sociais em sua totalidade.

É nesse ínterim que se constatou a importância de se iniciar este estudo pela reconstrução da história da pena da prisão, trazendo à tona a discussão sobre a indispensabilidade de uma análise com paradigma feminista para a real compreensão do crescimento do aprisionamento feminino atualmente. Tal abordagem pode ser capaz de dar voz àquelas que foram historicamente silenciadas em suas necessidades sociais, políticas e culturais.

No estudo quedou-se claro que a grande maioria das mulheres em situação de cárcere vive em um cenário de negligência, sendo a realidade brasileira marcada pelo processo de criminalização da miséria. Constatou-se, assim, que as ações institucionais vêm se desenvolvendo sem nenhum planejamento que leve em consideração a humanização da execução penal, violando o direito a uma vida digna, principalmente referente à realidade de mães presas e seus filhos.

O que se constata, portanto, é a necessidade da criação de políticas públicas específicas, pautadas para prevenir as situações de vulnerabilidade que têm orientado essas mulheres para o ingresso no crime, principalmente ao de tráfico de drogas, bem como oportunizar, àquelas que já estão nas prisões, alternativas de geração de trabalho e renda. 


\section{REFERÊNCIAS}

ALVES, Branca Moreira; PITANGUY, Jacqueline. O que é feminismo. São Paulo: Brasiliense, 2007.

ALVES, Fernando de Brito; RIGÃO, Livia Carla Silva. Cultura da periferia e as canções de rap: um olhar para as "vozes silenciadas" a partir da filosofia de Enrique Dussel. Revista Direitos Sociais e Políticas Públicas - Unifafibe, v. 8, n. 1, 2020.

ANDRADE, Vera Regina Pereira de. Sistema penal máximo x cidadania mínima: códigos da violência na era da globalização. Porto Alegre: Livraria do Advogado Editora, 2003.

ANDRADE, Vera Regina Pereira de. A soberania patriarcal: o sistema de justiça criminal no tratamento da violência sexual contra a mulher. Revista de Direito Público, n. 17, p. 52-75, jul./ago./set. 2007.

ANDRADE, Vera Regina Pereira de. Pelas mãos da criminologia: o controle penal para além da (des)ilusão. Rio de Janeiro: Revan; ICC, 2012.

ANDRECIOLI, S. M.; SIQUEIRA, D. P. Mulheres em situaação de cárcere: a importância da aplicação de um paradigma feminista. Direito penal, processo penal e Constituição I. In: ENCONTRO NACIONAL DO CONPEDI, 28., 2019. Goiânia: Conpedi, 2019.

ANITUA, Gabriel Ignacio. História dos pensamentos criminológicos. Rio de Janeiro: Revan, 2008.

ÁVILA, Gustavo Noronha de. Falsas memórias e sistema penal: a prova testemunhal em xeque. Rio de Janeiro: Lumen Juris, 2013.

BANDEIRA, Lourdes; SIQUEIRA, Deise. A perspectiva feminista no pensamento moderno contemporâneo. In: Sociedade e estado. Feminismos e gênero. Brasília: Departamento de Sociologia da Universidade de Brasília, 1997.

BARATTA, Alessandro. O paradigma de gênero: da questão criminal à questão humana. In: CAMPOS, Carmen Hein de (org.). Criminologia e feminismo. Porto Alegre: Sulina, 1999. p. 19-80.

BATISTA, Vera Malaguti. Introdução crítica à criminologia brasileira. Rio de Janeiro: Revan, 2011.

BATITUCCI, Eduardo Cerqueira. Aspectos da abordagem sociológica do crime e da prisão. Belo Horizonte: Fundação João Pinheiro, 1999.

BEAUVOIR, Simone de; MILLIET, Sérgio. O segundo sexo. Rio de Janeiro: Nova Fronteira, 2014.

BEIRAS, Iñaki Rivera. Desencarceramento: por uma política de redução da prisão a partir de um garantismo radical. Tradução Bruno Rotta Almeida e Maria Palma Wolff. 1. ed. Florianópolis: Tirant Lo Blanch, 2019.

BICALHO, Elizabete. Correntes feministas e abordagens de gênero. In: SOTER - Sociedade de Teologia e Ciências da religião. Gênero e teologia: interpelações e perspectivas. São Paulo: Soter, 2003.

BITENCOURT, Cezar Roberto; PRADO, Luiz Régis. Elementos de Direito Penal; Parte Geral. São Paulo: Revista dos Tribunais, 1995. V. 1.

BITENCOURT, Cezar Roberto. Falência da pena de prisão. São Paulo: Saraiva, 2017.

BOURDIEU, Pierre. A dominação masculina: a condição feminina e a violência simbólica. 11. ed. Trad. Maria Helena Kuhner. Rio de Janeiro: Bertrand Brasil, 2012.

BRASIL. Constituição da República Federativa do Brasil de 1988. Disponível em: http://www.planalto.gov.br/ccivil_03/constituicao/constituicao.htm. Acesso em: jun. 2019.

BRASIL. Ministério da Justiça. Levantamento Nacional de Informações Penitenciárias - Infopen. Brasília, DF, 2017a. Disponível em: http://depen.gov.br/DEPEN/depen/sisdepen/infopen/relatorio_2016_22-11.pdf. Acesso em: jun. 2019.

BRASIL. Ministério da Justiça. Levantamento Nacional de Informações Penitenciárias - Infopen Mulheres. Brasília, DF, 2017b. Disponível em: http://depen.gov.br/DEPEN/depen/sisdepen/infopen-mulheres/infopenmulheres_arte_07-03-18.pdf. Acesso em: jun. 2019.

BRYSON, Valerie. Feminist Political Theory: an introduction. 2. ed. Hampshire; New York: Palgrave Macmilan, 2003.

CAPELO DE SOUSA, Rabindranath Valentino Aleixo. Direito geral de personalidade. Coimbra: Coimbra Editora, 1995.

CARRANZA, Elías. Situación penitenciaria en América Latina y el Caribe ¿Qué hacer? Anuario de Derechos Humanos, 8, 2012, p. 31-66. Disponível em: https://anuariocdh.uchile.cl/index.php/ADH/article/view/20551/21723. Acesso em: set. 2019.

CARVALHO, Daniela Tiffany Prado; MAYORGA, Claudia. Contribuições feministas para os estudos acerca do aprisionamento de mulheres. Revista de Estudos Feministas, v. 25, p. 99-116, 2017.

CARVALHO, Salo. A política criminal de drogas no Brasil: estudo criminológico e dogmático da Lei 11.343/06. Rio de Janeiro: Lumen Juris, 2010. 
CASAGRANDE, Carla. A mulher sob custódia. In: PERROT, Michelle; DUBY, Georges (org.). História das mulheres no ocidente. Idade Média. Porto: Afrontamento, 1990. p. 99-141. V. 2.

CASTRO, Alexander; NASCIMENTO, Gabriel Bassaga. Liberdade de expressão frente à liberdade religiosa: direitos fundamentais em conflito e proteção de direitos da personalidade frente a discursos de ódio. Revista Direitos Sociais e Políticas Públicas - Unifafibe, v. 7, n. 3, 2019.

CIPR. Institute for Criminal Policy Research. Relatório 2018. Word Prison Population List, 2018

COSTA, Fabrício Veiga; PINTO, Alisson Alves. A ressocialização do detento a partir do prazo para o cumprimento da função social da empresa na sociedade contemporânea. Revista Direitos Sociais e Políticas Públicas - Unifafibe, v. 7, n. 3, 2019.

CUNHA, Manuela Ivone. A reclusão segundo o gênero: os estudos prisionais, a reclusão de mulheres e a variação dos contextos de identidade. In: AAVV Educar o Outro: as questões de gênero, dos direitos humanos e da educação nas prisões portuguesas. Coimbra: Publicações Humanas, 2007.

FERREIRA, Verônica. Entre emancipadas e quimera - imagens do feminismo no Brasil. Cadernos AEL, n. 3/4, p. 153-200, 1995-1996.

FOUCAULT, Michel. História da loucura na Idade Clássica. Tradução José Teixeira Coelho Netto. São Paulo: Perspectiva, 1978.

FOUCAULT, Michel. Microfísica do poder. Rio de Janeiro: Graal, 1969.

FOUCAULT, Michel. Vigiar e punir. História da violência nas prisões. Petrópolis: Vozes, 2007.

FRANÇOISE, d' Eaubonne. Féminisme ou la mort (Le). Paris: Passager clandestin (Le), 1974.

GARCÍA VALDÉS, Carlos. Estudios de derecho penitenciário. Madrid: Tecnos, 1982.

GARCÍA, Eusebio Fernández. Dignidad Humana y Ciudadanía Cosmopolita. Cuadernos Bartolomé de las Casas, Madrid: Dykinson, n. 21, 2001.

GARRIDO GUZMAN, Luiz. Compendio de ciencia penitenciária. Valencia: Universidad de Valencia, 1976.

GOFFMAN, Erving. Estigma: notas sobre a manipulação da identidade deteriorada. Rio de Janeiro: Zahar Editores, 1975.

HENTIG, Hans Von. La pena. Madrid: Espasa-Calpe, 1967. V. 1.

HITA, Maria Gabriela. Igualdade, identidade e diferença (s): feminismo na reinvenção de sujeitos. In: BUARQUE DE ALMEIDA, Heloísa et al. (org.). Gênero e matizes. São Paulo: Edusf, 2002.

KOLKER, Tania. A atuação do psicólogo no sistema prisional. In: GONÇALVES, Hebe Signorini; BRANDÃO, Eduardo Ponte (org.). Psicologia jurídica no Brasil. Rio de Janeiro: Nau Editora, 2004.

LAZCANO, Alfonso Jaime Martínez. El derecho convencional y los retos de su implementación en los estados parte. Revista Direitos Sociais e Políticas Públicas - Unifafibe, v. 7, n. 3, 2019.

LEAL, César Barros. Prisão: crepúsculo de uma era. 2. ed. Belo Horizonte: Del Rey, 2001.

LEGATES, M. In Their Time: a history of feminism in western society. New York: Routledge, 2001.

LOZANO, Luis Gerardo Rodrígues. León duguit y el servicio público: ideas para el siglo XXI. Revista Direitos Sociais e Políticas Públicas - Unifafibe, v. 8, n. 1, 2020.

LUCAS, Doglas Cesar. Direitos humanos, identidade e a política de reconhecimento de Charles Taylor. Revista Direitos Sociais e Políticas Públicas - Unifafibe, v. 7, n. 3, 2019.

MACHADO, Lia Zanotta. Gênero, um novo paradigma? Cadernos Pagu, Campinas, SP, n. 11, p. 107-125, jan. 2013. ISSN 1809-4449. Disponível em: https://periodicos.sbu.unicamp.br/ojs/index.php/cadpagu/article/ view/8634467/2391. Acesso em: 12 fev. 2019.

MACHADO, Robson Aparecido. A realidade do egresso: plano normativo da lei de execução penal versus reintegração social. Revista Direitos Sociais e Políticas Públicas - Unifafibe, v. 3, n. 1, 2015.

MAGLIACANE, Alessia. L'armee des reserves dans la mondialisation: la parabole de la femme italienne de la constitution au post-fordisme. Revista Direitos Sociais e Políticas Públicas - Unifafibe, v. 7, n. 3, 2019.

MARTíN, Ignacio Durbán Origen y fundamentos del sistema plurilegislativo civil español. Revista Direitos Sociais e Políticas Públicas - Unifafibe, v. 8, n. 1, 2020.

MARTINS, Argemiro Cardoso Moreira. O direito romano e seu ressurgimento no final da Idade Média. In: WOLKMER, Antonio Carlos (org.). Fundamentos de história do direito. Belo Horizonte: Del Rey, 2011.

MELOSSI, Dario; PAVARINI, Massimo. Cárcel y fábrica; los orígenes del sistema penitenciário, siglos XVI-XIX. 2. ed. México: Siglo XXI Ed., 1985.

MENDES, S. R. Criminologia feminista: novos paradigmas. 2. ed. São Paulo: Saraiva, 2017. p. 215. 
MENDES, S. R. Tecendo uma criminologia feminista no Brasil. Labrys (Edição em Português. on-line), v. 31, 2018. Disponível em: https://www.labrys.net.br/labrys31/criminologie/soraia.htm.

MERTON, Robert King. Sociologia: teoria e estrutura. São Paulo: Mestre Jou, 1970.

MIRABETE, Júlio Fabbrini. Execução penal: comentários à Lei no 7.210, de 11/07/84. 9. ed. rev. e atual. São Paulo: Atlas, 2000.

MORAES, Maria Valentina de; LEAL, Mônia Clarissa Hennig. Supremo tribunal federal e diálogo institucional: há um controle jurisdicional de políticas públicas no brasil? Revista Direitos Sociais e Políticas Públicas - Unifafibe, v. 7, n. 3, 2019.

NARAYAN, Uma. O projeto da epistemologia feminista: perspectivas de uma feminista não ocidental. In: JAGGAR, Alison M.; BORDO, Susan (org.). Gênero, corpo e conhecimento. Rio de Janeiro: Record: Rosa dos Tempos, 1997. NEUMAN, Elías. El problema sexual em las cárceles. Argentina: Ed. Criminalia, 1965.

OLIVEIRA, Adriana Vidal de. A expressão constituinte do feminismo: por uma retomada do processo liberatório da mulher. 2007. 179 f. Dissertação (Mestrado) - Pontifícia Universidade Católica do Rio de Janeiro, Rio de Janeiro, 2007.

OPTIZ, Claudia. O quotidiano da mulher no final da Idade Média (1250-1500). In: PERROT, Michelle; DUBY, Georges (org.). História das mulheres do ocidente. Idade Média. Porto: Afrontamento, 1990. V. 2.

PINTO, Célia Regina Jardim. Feminismo, história e poder. Rev. Sociol. Polit., Curitiba, v. 18, n. 36, p. 15-23, jun. 2010. p. 15. Disponivel em: http://www.scielo.br/scielo.php?script=sci_arttext\&pid=\$010444782010000200003\&ln$\mathrm{g}=$ en\&nrm=iso. Acesso em: $20 \mathrm{fev} .2019$.

PIOVESAN, Flávia. A proteção internacional dos direitos humanos das mulheres. Revista da Emerj, v. 15, p. 70-89, 2012.

PRÁ, Jussara Reis. O feminismo como teoria e como prática política. In: STREY, Marlene Neves. Mulher: estudos de gênero. São Leopoldo: Unisinos, 1997. p. 39-57.

ROUSSEAU, Jean Jacques. Do contrato social: discurso sobre a economia política. Trad. Márcio Pugliesi e Norberto de Paula Lima. 7. ed. Curitiba: Editora Hemus, 1981.

RUETHER, R. R. Sexismo e religião: rumo a uma teologia feminista. São Leopoldo: Sinodal, 1993.

RUSCHE, Georg; KIRCHHEIMER, Otto. Punição e estrutura social. Rio de Janeiro: Revan, 2004.

SAFFIOTI, Heleieth lara Bongiovani. A mulher na sociedade de classes: mito e realidade. 2. ed. Petrópolis: Vozes, 1976.

SAFFIOTI, Heleieth lara Bongiovani. Feminismos e seus frutos no Brasil. In: SADER, Emir. Movimentos sociais na transição democrática. São Paulo: Ed. Cortez, 1987. p. 105-157.

SANTA RITA, Rosangela Peixoto. Mães e crianças atrás das grades: em questão o princípio da dignidade da pessoa humana. 2006. 162 p. Dissertação (Mestrado em Política Social) -Universidade de Brasília, Brasília, 2006.

SANTOS, Marcel Ferreira; ÁVILA, Gustavo Noronha. Encarceramento em massa e estado de exceção: o julgamento da Ação de Descumprimento de Preceito Fundamental 347. Revista Brasileira de Ciências Criminais, v. 136, p. 267-291, 2017.

SEN, Amartya. Desenvolvimento como liberdade. São Paulo: Companhia das Letras, 2000.

SIQUEIRA, D.; ANDRECIOLI, S. A vulnerabilidade das mulheres encarceradas e a justiça social: o importante papel da educação na efetividade no processo de ressocialização. Revista Direito em Debate, v. 28, n. 51, p. 61-77, 7 ago. 2019.

SOARES, Bárbara Musumeci; ILGENFRITZ, lara. Prisioneiras: vida e violência atrás das grades. Rio de Janeiro: Garamond, 2002.

SZANIAWSKI, Elimar. Direitos de personalidade e sua tutela. 2. ed. São Paulo: Revista dos Tribunais, 2005.

TOUPIN, Louise. Les courants de pensée feministe. 1998. p. 11. Disponível em: http://classiques.uqac.ca/contemporains/toupin_louise/courants_pensee_feministe/courants_pensee_feministe.pdf. Acesso em: 20 fev. 2019.

WOOLF, Virginia. Professions for Women. In: BARRETTT, Michèle. Virginia Woolf: Women and Writing. Virago: London, 1931.

WOOLF, Virginia. Um teto todo seu. Rio de Janeiro: Nova Fronteira, 1985.

ZAFFARONI, E. Raúl. A mulher e o poder putivo. In: CLADEM. Mulheres: vigiadas e castigadas. São Paulo: Cladem, 1995.

ZAFFARONI, E. Raúl. Em busca das penas perdidas: a perda de legitimidade do sistema penal. Tradução Vania Romano Pedrosa e Amir Lopez da Conceição. Rio de Janeiro: Revan, 1991. 